\title{
A Damage-Based Analysis of Rework in Reconstruction of Infrastructure Projects Due to Natural Disasters
}

\author{
Elnaz Safapour ${ }^{1}$, Sharareh Kermanshachi ${ }^{2}$ and Thahomina Jahan Nipa ${ }^{3}$
}

1 Department of Civil Engineering, University of Texas at Arlington, Arlington, USA, elnaz.safapour@mavs.uta.edu

2 Department of Civil Engineering, University of Texas at Arlington, Arlington, USA, sharareh.kermanshachi@uta.edu

3 Department of Civil Engineering, University of Texas at Arlington, Arlington, USA, thahomina.nipa@mavs.uta.edu

\begin{abstract}
The number of reworks and their corresponding costs are usually much higher for reconstruction projects than for construction projects. Even though a significant amount of research has been conducted to identify the causes and factors of rework, none have been based on post-disaster reconstruction. Therefore, it is the aim of this study, is to identify and categorize the critical factors that initiate the rework and affect the cost of post-disaster reconstruction of transportation infrastructures (PRTs). To fulfill that goal, a survey of 46 questions was developed and distributed. Thirty (30) completed responses were collected from a group of respondents who were owners, program managers, project managers, and engineers with experience in working on a reconstruction project. The responses were analyzed statistically, and it was found that when the reconstruction of a transportation project is complex, the number and cost of reworks rise significantly. It was also found that the number of reworks is directly related to the level of damage to the infrastructure, which means that skilled and experienced project managers must be assigned to the project so that the fast decision-making process can be ensured to avoid the excessive amount of reworks. The findings of this study will help decision-makers and program managers prevent undue expenses and delays in the restoration of damaged infrastructure after natural disasters and hurricanes.
\end{abstract}

(c) 2020 The Authors. Published by Budapest University of Technology and Economics \& Diamond Congress Ltd Peer-review under responsibility of the Scientific Committee of the Creative Construction Conference 2020.

Keywords: cost of rework, level of damage, post-disaster reconstruction, reconstruction of transportation infrastructure

\section{Introduction}

Rework is one of the major causes of cost and schedule overruns of construction projects $[1,2,3,4]$. In 2011 , research was conducted by the Construction Industry Institute, and it was found that the direct cost of reworks of a construction project reach $20 \%$ of the project's contracted amount [5]. Shahparvari and Fong [6] found that the cost of rework, which is different for each project, can be up to $70 \%$ of the total project cost. Hence, the cost of rework is considered an indicator of the execution performance of a project $[7,8,9]$. Rework also acts as a catalyst in the reduction of organizational performance by demotivating the workers [10,11]. Even though rework affects different projects in different ways [12], the sources of the reworks with substantial impacts are not drastically different [13].

Post-disaster reconstruction projects often suffer from unwanted and unprecedented reworks [14]. The number of reworks, as well as the cost of rework, is usually much higher in reconstruction projects compared to construction projects $[7,15]$. The construction industry is one of the industries with most 
uncertainties in the world [16], and reconstruction projects are even riskier, as they encompass additional safety requirements and time, cost, and space limitations [17]. The cost and time-sensitive nature of the projects require that they be performed in such a way that the negative impacts on the budget and schedule can be avoided $[18,19,20]$. Reworks in post-disaster reconstruction of transportation infrastructures is especially harmful, as it not only slows down the recovery of the damaged transportation infrastructure, but also indirectly slows down the overall recovery of the community [21]. Despite a significant number of researches in the literature regarding the causes and factors of reworks in the construction industry [22, 23], there are few such studies based on post-disaster reconstruction.

The aim of this study is to identify and categorize the critical factors that initiate reworks and affect their cost in the post-disaster reconstruction of transportation infrastructures (PRTs). To fulfill the goals of this study, several research objectives were formulated: i) identify potential PRTs leading to rework in postdisaster reconstruction projects of transportation infrastructures, ii) determine significant PRTs leading to rework of reconstruction projects, and iii) determine significant PRTs affecting the cost of reworks associated with the damage level of the infrastructure. The findings of this study will help decision-makers and program managers prevent undue expenses and delays in the restoration of damaged infrastructures after natural disasters, and hurricanes in particular.

\section{Literature review}

Almost every community suffers from casualties and losses due to natural disasters at some time [24, 25] and there has been an increase in the number of natural disasters over the last couple of decades [26, 27]. One of the most devastating natural disasters are hurricanes, which are increasing in intensity and frequency [28]. On average, every year, the United States of America suffers from two hurricanes [29]. They disrupt community life by causing physical, psychological, and environmental distress, especially when the society is not sufficiently equipped to handle the disaster [30]. For example, Hurricane Katrina in New Orleans caused $\$ 1845$ billion of damage, and Hurricane Rita caused $\$ 120$ billion of damage in 2005 in areas surrounding the Gulf of Mexico [31, 32].

These disasters usually cause the greatest damage to the transportation infrastructures, which makes the reconstruction costly and time-consuming [30, 33, 34]. Functioning transportation systems are a prerequisite for the mobility of the public and for economic growth [35]. A damaged transportation system cannot facilitate the usual traffic flow, hinders emergency response, causes indirect losses, and increases the sufferings of the people in the affected community [36, 37, 38]. In 1991, the Northridge disaster disrupted critical highways in the Los Angeles area, and a ripple effect caused the closure of several parts of Interstate 10 and resulted in $\$ 1$ million of economic loss each day for several days [39]. To avoid these unwanted and unforeseen economic losses and human suffering, it is vital that damaged transportation infrastructures be reconstructed as soon after the disaster as possible [40].

Resource constraints are a common side effect of post-disasters [41], and the shortages can have a major impact on the recovery of transportation infrastructures [27, 42, 43]. A project can be identified as successful when the completion time and cost are within the initially estimated schedule and budget, respectively $[44,45]$. However, reconstruction projects are not only complex, but also have a chaotic and dynamic nature that can cause unpredictable changes in the middle of a project and require reworks [46, 47, 48]. Aljailawi and Shariatmadar [49] defined rework as efforts that are unnecessary and only required when the activity was not done properly the first time. The number of reworks can highly increase the cost and time of the project [18]. Conversely, the reduction of reworks ensures sustainable development, as less rework means that fewer materials are wasted [49]. Amaratunga et al. [50] found that reducing reworks can highly improve the performance of reconstruction projects.

In a nutshell, the success of post-disaster reconstruction depends upon the project being on time, within budget, and with the least possible number of reworks. However, many researchers have identified factors that might cause cost overruns, schedule overruns, and an extensive number of reworks, and a list of them is presented in Table 1. 
Table 1. Challenges that affect cost, schedule, and number of reworks of a post-disaster reconstruction project

\begin{tabular}{lc}
\hline \multicolumn{1}{c}{ Challenge } & Previous Study \\
\hline Resources are not delivered within the deadline & {$[51]$} \\
\hline Not having sufficient funds & {$[52]$} \\
\hline Faulty assessment of the situation & {$[53]$} \\
\hline Lack of communication and disorder in coordination & {$[54]$} \\
\hline Faulty design & {$[55]$} \\
\hline Transportation & {$[56]$} \\
\hline Difficulty in arranging temporary paths & {$[57]$} \\
\hline Faulty assessment of the level of damage & {$[58]$} \\
\hline Shortage of laborers & {$[18]$} \\
\hline Shortage of materials & {$[18]$} \\
\hline Inability to make impromptu decisions & {$[59]$} \\
\hline Inexpert inspectors & {$[60,61]$} \\
\hline
\end{tabular}

\section{Research methodology}

The four-step methodology shown in Figure 1 was adopted for this study. The first step was focused on a review of the existing literature. A preliminary search via popular search engines resulted in 500 articles. The secondary screening process was conducted by scrutinizing the titles and abstracts of the papers, and 89 articles were shortlisted. The shortlisted articles were studied and, based on the information gathered, a list of 30 potential PRTs was prepared. In the second step, a survey was developed and distributed after pilot testing, and 30 completed responses were collected. In the third step, a descriptive analysis of the cost of the reworks and level damage of the infrastructure was conducted. In the last step, the data were analyzed quantitatively and the significant PRTs were identified.

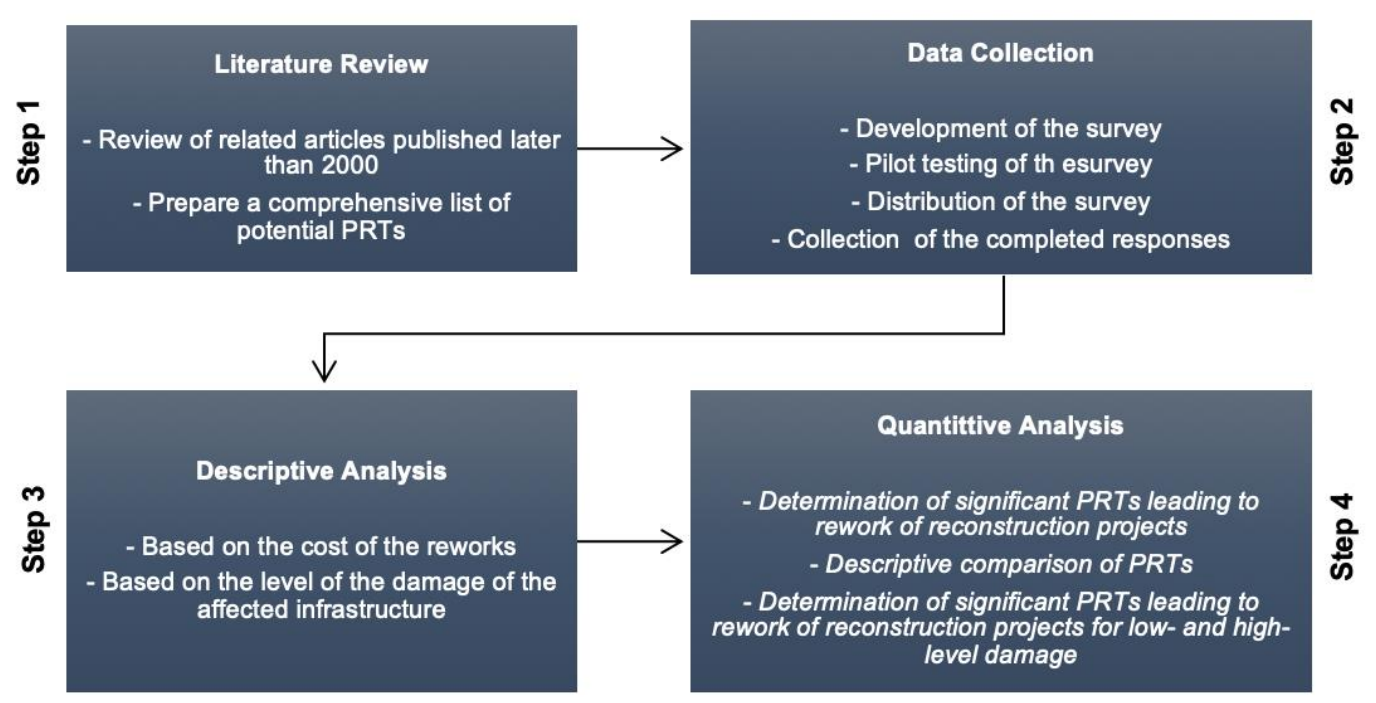

Fig. 1. Research methodology

\section{Data collection}

\subsection{Development of the list of PRTS}

A keyword search method through popular search engines like Google Scholar, JSTOR, ProQuest, etc. resulted in the collection of approximately 500 scholarly articles. The titles and abstracts of the collection were scrutinized, and 89 articles that were considered the most relevant were shortlisted. The shortlisted articles were studied thoroughly, and pertinent information was entered into a database that was used, along with the expertise and experience of the authors, to prepare a list of 30 potential PRTs. Table 2 shows the identified PRTs. 
Table 2. list of potential PRTs

\begin{tabular}{ll}
\hline \multicolumn{1}{c}{ List of PRTs } & \multicolumn{1}{c}{ List of PRTs } \\
\hline PRT1. Number of main/truck lines & PRT16. Quality issues of materials \\
PRT2. Total length & PRT17. Quality issues of equipment \\
PRT3. Level of complexity & PRT18. Frequency level of logistics management issues \\
PRT4. Distance from highly populated area & PRT19. Quality of on-site inspections \\
PRT5. Level of damage & PRT20. Frequency of on-site inspections \\
PRT6. Level of traffic disturbance & PRT21. Information management \\
PRT7. Shortage of experts & PRT22. Pace of decision-making process \\
PRT8. Shortage of field laborers & PRT23. Implementation level of risk management \\
PRT9. Productivity level of contractors & PRT24. Coordination \\
PRT10. Shortage of materials & PRT25. Pace of workers' mobilization \\
PRT11. Shortage of equipment & PRT26. Volume of debris \\
PRT12. Inflation of labor wages & PRT27. Environmental/safety issues prior to execution of the project \\
PRT13. Availability level of on-site infrastructure & PRT28. Work suspension through execution of the project \\
PRT14. On-site accommodation level for staff & PRT29. Regulatory requirement \\
PRT15. Shortage of supplier & PRT30. Availability of required temporary pathways \\
\hline
\end{tabular}

\subsection{Survey development, distribution, and collection}

After identifying the potential PRTs, a structured survey was constructed that converted each PRT into a question. The participants were also asked to provide demographic information and to name a postdisaster transportation reconstruction project that they had worked on. The survey consisted of 46 questions of three kinds: i) continuous questions, ii) seven-point Likert scale questions, and iii) binary questions. Two sample questions of the survey are presented in Figure 2.

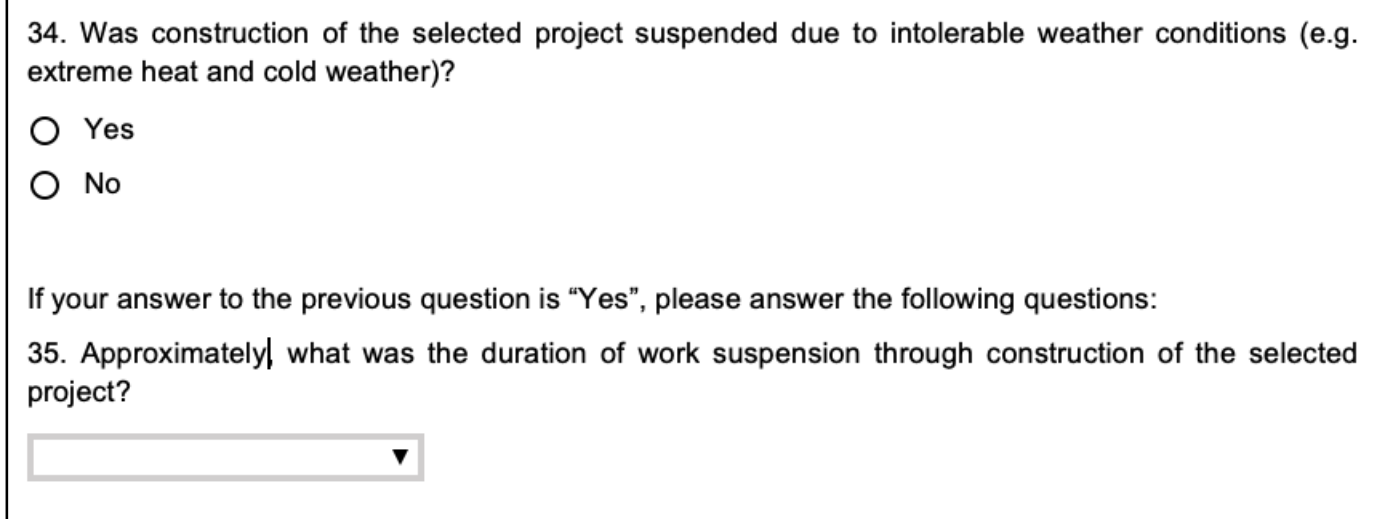

Fig. 2. Sample survey questions

The survey was pilot tested to determine its suitability for the participants, and it was modified, based on the responses of those participating in the testing.

A list was developed of potential respondents who were owners, project managers, program managers, and engineers. The respondents were contacted by email, and upon their agreement the survey was sent to them electronically. After several follow-up emails, 30 completed responses were collected.

\section{Descriptive analysis}

\subsection{Based on the cost of the project and the cost of rework}

Table 3 shows the minimum, mean, and maximum values for the cost of the projects and the cost of the reworks. The mean and maximum cost values of the reworks were roughly $\$ 270,000$ and $\$ 1$ million, respectively.

Table 7: Descriptive Data Analysis

\begin{tabular}{llcccc}
\hline & & Minimum & Mean & Maximum & Standard Deviation \\
\hline \multirow{2}{*}{ Cost } & Baseline Budget & $\$ 300 \mathrm{~K}$ & $\$ 22,930 \mathrm{~K}$ & $\$ 100,000 \mathrm{~K}$ & $\$ 33,200 \mathrm{~K}$ \\
& Actual Cost & $\$ 500 \mathrm{~K}$ & $\$ 36,540 \mathrm{~K}$ & $\$ 150,000 \mathrm{~K}$ & $\$ 53,110 \mathrm{~K}$ \\
\hline Rework & Cost & $\$ 50 \mathrm{~K}$ & $\$ 264 \mathrm{~K}$ & $\$ 1,000 \mathrm{~K}$ & $\$ 361 \mathrm{~K}$ \\
\hline
\end{tabular}




\subsection{Based on the level of damage}

In response to a query about the level of damage sustained by the infrastructure that the survey respondents were involved with following a natural disaster, they revealed almost $30 \%$ of the projects had infrastructures that were damaged more than $80 \%$ and around $20 \%$ of the projects had infrastructures that were damaged less than $40 \%$.

\section{Quantitative analysis}

\subsection{Determination of significant PRTs leading to rework of reconstruction projects}

The PRTs that significantly lead to reworks in reconstruction projects are shown in Table 4. The two-sample t-test, Kruskal-Wallis, and Chi-squared test were performed according to the appropriate type of data. To avoid any bias created by including large projects in the results, the cost of the issued rework was normalized based on project size. To calculate the normalized cost of rework for any project, the cost of the rework was divided by the baseline budget for the construction phase. These costs were recorded and used for the remainder of the analyses conducted for this study. Table 4 presents that 22 PRTs were recorded as significant in deriving reworks in reconstruction projects.

Table 4. Results of significant PRTs leading to rework in reconstruction projects

\begin{tabular}{|c|c|c|}
\hline Category & List of PRTs & $P$-Value \\
\hline & PRT1. Number of main/truck lines & $0.021^{\star *}$ \\
\hline Physical & PRT2. Total length & 0.256 \\
\hline \multirow[t]{2}{*}{ Characteristics } & PRT3. Level of complexity & $0.062^{*}$ \\
\hline & PRT4. Distance from highly populated area & $0.011^{\star \star}$ \\
\hline Damaging & PRT5. Level of damage & $0.018^{\star \star}$ \\
\hline Level & PRT6. Level of traffic disturbance & 0.637 \\
\hline \multirow{9}{*}{ Resource } & PRT7. Shortage of experts & $0.033^{\star *}$ \\
\hline & PRT8. Shortage of field laborers & $0.014^{\star \star}$ \\
\hline & PRT9. Productivity of contractors & $0.072^{*}$ \\
\hline & PRT10. Shortage of materials & $0.054^{*}$ \\
\hline & PRT11. Shortage of equipment & $0.036^{\star *}$ \\
\hline & PRT12. Inflation of labor wages & 0.333 \\
\hline & PRT13. Availability of on-site infrastructure & $0.044^{*}$ \\
\hline & PRT14. On-site accommodation level for staff & $0.078^{*}$ \\
\hline & PRT15. Productivity of suppliers & $0.002^{* *}$ \\
\hline \multirow{2}{*}{ Quality } & PRT16. Quality issues of materials & $0.029^{\star *}$ \\
\hline & PRT17. Quality issues of equipment & $0.066^{*}$ \\
\hline \multirow{8}{*}{$\begin{array}{l}\text { Project } \\
\text { Management }\end{array}$} & PRT18. Number of logistics management issues & $0.088^{*}$ \\
\hline & PRT19. Quality of on-site inspections & $0.034^{\star \star}$ \\
\hline & PRT20. Number of on-site inspections & $0.019^{* *}$ \\
\hline & PRT21. Information management & $0.093^{*}$ \\
\hline & PRT22. Pace of decision-making process & $0.080^{*}$ \\
\hline & PRT23. Implementation level of risk management & $0.019^{* *}$ \\
\hline & PRT24. Coordination & $0.077^{*}$ \\
\hline & PRT25. Pace of workers' mobilization & 0.155 \\
\hline Environment & PRT26. Volume of debris & 0.474 \\
\hline & PRT27. Environmental/safety issues prior to execution of the project & 0.212 \\
\hline Safety & PRT28. Work suspension through execution of the project & 0.652 \\
\hline Legal & PRT29. Regulatory requirement & $0.001^{* *}$ \\
\hline Local & PRT30. Availability of required temporary pathways & 0.177 \\
\hline
\end{tabular}

As presented in Table 4, the lack of frequent on-site inspections (PRT-20, belonging to the category of project management) and low quality of on-site inspections (PRT-19, belonging to the category of project management) leads to decreased productivity and waste of limited post-hurricane resources. The lack of adequate quality and sufficient quantity of on-site inspections results in inadequate documentation and records and often causes duplications of efforts and an increase in the number and cost of reworks.

Table 4 indicates that when the reconstruction of a transportation project is complex (PRT-3, belonging to physical characteristics), skilled and experienced site laborers and project managers need to be involved in 
the project. After a disaster, clients are usually faced with a shortage of human resources; therefore, when the reconstruction project is complex, the probability of reworks being needed might remarkably increase.

\subsection{Descriptive comparison of PRTs affecting rework of reconstruction projects}

A descriptive comparison of the mean values of reconstruction projects with low costs of reworks and high costs of reworks associated with continuous data are shown in Table 5 . The mean values of PRTs 1, 4, and 5 are significantly different. For instance, the average distance of a project's location from a highly populated area (PRT-4) in a project with a low cost of rework (12.5 miles) is very different from the same project with a high cost of rework (30.5 miles). The mean of the damage level for reconstruction projects with a low cost of rework was $50 \%$, while the same average for projects with a high cost of rework was $70 \%$. Therefore, it was concluded from Table 5 that reconstruction projects with poor performance are more complicated than those with good performance.

Table 5. Comparative analysis of PRTs affecting cost of rework - continuous data

\begin{tabular}{lcc}
\hline \multirow{2}{*}{ List of PRTs } & \multicolumn{2}{c}{ Average } \\
\cline { 2 - 3 } & $\begin{array}{l}\text { Low Cost } \\
\text { of Rework }\end{array}$ & $\begin{array}{c}\text { High Cost } \\
\text { of Rework }\end{array}$ \\
\hline PRT1. Number of main/truck lines & 9 & 3 \\
PRT4. Distance from highly populated area & $12.5 \mathrm{mi}$ & $30.5 \mathrm{mi}$ \\
\hline PRT5. Level of damage & $50 \%$ & $70 \%$ \\
\hline
\end{tabular}

\subsection{Determination of significant PRTs leading to rework of reconstruction projects for low-and high-level damage}

In this step, the PRTs that significantly affect the cost of reworks associated with the two groups (highly damaged and low-level damage) were statistically determined and presented (Table 6). Three types of statistical analysis methods, the two-sample t-test, Chi-Square, and Kruskal-Wallis test were adopted according to the type of data. Table 6 indicates that 24 of the 29 PRTs were determined statistically significant for highly damaged reconstruction projects, and 20 PRTs were recorded as statistically significant for low-level damaged reconstruction projects.

As presented in Table 6, the availability of PRT-1 (number of main lines), PRT-3 (level of complexity), and PRT-4 (distance from the highly populated area), belonging to the category of physical characteristics, make reconstruction projects more complicated and increase the number of uncertainties and risks. These issues lead to suspension of the projects, frustrate the team members, and foster low productivity, thereby increasing the number and cost of the reworks.

Information management (PRT-21) also plays a critical role in post-hurricane reconstruction projects by tracking projects' resources, improving budgeting and cost analyses, and mitigating risks. Lack of information management seriously affects the quality of project management and results in more reworks.

Table 6. Results of significant PRTs affecting rework regarding damage level in reconstruction projects

\begin{tabular}{|c|c|c|c|}
\hline \multirow[b]{2}{*}{ Category } & \multirow[b]{2}{*}{ List of PRTs } & \multicolumn{2}{|c|}{$P$-Value } \\
\hline & & $\begin{array}{c}\text { Highly } \\
\text { Damaged }\end{array}$ & $\begin{array}{l}\text { Low Level } \\
\text { Damaged }\end{array}$ \\
\hline \multirow{4}{*}{$\begin{array}{c}\text { Physical } \\
\text { Characteristics }\end{array}$} & PRT1. Number of main/truck lines & $0.029^{\star \star}$ & $0.025^{\star *}$ \\
\hline & PRT2. Total length & 0.254 & 0.359 \\
\hline & PRT3. Level of complexity & $0.092^{*}$ & $0.083^{*}$ \\
\hline & PRT4. Distance from highly populated area & $0.028^{\star *}$ & $0.013^{\star *}$ \\
\hline $\begin{array}{c}\text { Damaging } \\
\text { Level }\end{array}$ & PRT6. Level of traffic disturbance & 0.634 & 0.179 \\
\hline \multirow{7}{*}{ Resource } & PRT7. Shortage of experts & $0.011^{\star *}$ & $0.016^{\star *}$ \\
\hline & PRT8. Shortage of field laborers & $0.091^{*}$ & $0.055^{*}$ \\
\hline & PRT9. Productivity of contractors & $0.071^{*}$ & $0.059^{*}$ \\
\hline & PRT10. Shortage of materials & $0.020^{\star *}$ & $0.089^{*}$ \\
\hline & PRT11. Shortage of equipment & $0.014^{*}$ & $0.001^{* *}$ \\
\hline & PRT12. Inflation of labor wages & 0.199 & 0.435 \\
\hline & PRT13. Availability of on-site infrastructure & $0.007^{\star *}$ & $0.031^{* *}$ \\
\hline
\end{tabular}




\begin{tabular}{|c|c|c|c|}
\hline & $\begin{array}{l}\text { PRT14. On-site accommodation level for staff } \\
\text { PRT15. Productivity of suppliers }\end{array}$ & $\begin{array}{l}0.088^{*} \\
0.059^{*}\end{array}$ & $\begin{array}{l}0.633 \\
0.074^{*}\end{array}$ \\
\hline \multirow{5}{*}{ Quality } & PRT16. Quality issues of materials & $0.016^{\star \star}$ & $0.027^{* *}$ \\
\hline & PRT17. Quality issues of equipment & $0.037^{\star \star}$ & $0.015^{\star *}$ \\
\hline & PRT18. Number of logistics management issues & $0.056^{*}$ & $0.072^{*}$ \\
\hline & PRT19. Quality of on-site inspections & $0.066^{*}$ & $0.028^{\star *}$ \\
\hline & PRT20. Number of on-site inspections & $0.080^{*}$ & $0.017^{* *}$ \\
\hline Project & PRT21. Information management & $0.069^{*}$ & $0.077^{*}$ \\
\hline \multirow[t]{4}{*}{ Management } & PRT22. Pace of decision-making process & $0.022^{\star *}$ & 0.759 \\
\hline & PRT23. Implementation level of risk management & $0.082^{*}$ & $0.032^{* *}$ \\
\hline & PRT24. Coordination & $0.022^{\star *}$ & $0.075^{\star}$ \\
\hline & PRT25. Pace of workers' mobilization & $0.058^{*}$ & 0.153 \\
\hline Environment & PRT26. Volume of debris & 0.195 & 0.174 \\
\hline \& & PRT27. Environmental/safety issues prior to execution of the project & 0.647 & 0.357 \\
\hline Safety & PRT28. Work suspension through execution of the project & $0.019^{\star *}$ & 0.754 \\
\hline Legal & PRT29. Regulatory requirements & $0.033^{\star *}$ & $0.001^{* *}$ \\
\hline Local & PRT30. Availability of required temporary pathways & 0.391 & 0.351 \\
\hline
\end{tabular}

\section{Conclusion}

The number of reworks has an appreciable negative impact on the construction, as well as post-disaster reconstruction, of transportation infrastructure systems. Even though there are a significant number of researches in the literature that identify the sources and factors of reworks in construction projects, few identify the factors that affect the reworks of post-disaster reconstruction. Therefore, this study aimed to identify and categorize the factors that lead to reworks in the post-disaster reconstruction of transportation infrastructures. For this purpose, a survey was developed, and 30 completed surveys were collected. The survey result was analyzed both qualitatively and quantitatively and revealed that when the reconstruction of a transportation project is complex, the number and cost of reworks is high, and skilled and experienced project managers must be assigned so that a rapid decision-making process can be ensured. It was also found that the number of reworks is directly correlated with the level of damage to the infrastructures. When the level of damage is comparatively high, skilled site laborers and project managers need to be involved in the project to avoid an excessive number of reworks. The findings of this study will help decisionmakers and program managers prevent undue expenses and delays in the restoration of damaged infrastructures after natural disasters, particularly hurricanes.

\section{References}

[1] L.O. Oyewobi, O. Abiola-Falemu, O., O.T. Ibironke. "The impact of rework and organisational culture on project delivery". Journal of Engineering, Design and Technology, 2016. https://doi.org/10.1108/JEDT-05-2013-0038

[2] Kermanshachi, s. "Decision making and uncertainity analysis in success of construction projects". Ph.D. Dissertation, Texas A \& M University, 2016.

[3] Habibi M, Kermanshachi S, Rouhanizadeh B. "Identifying and Measuring Engineering, Procurement, and Construction (EPC) Key Performance Indicators and Management Strategies". Infrastructures 4(14), 2019. https://doi.org/10.3390/infrastructures4020014

[4] Kermanshachi S, Beaty C, Anderson S D. "Improving Early phase cost estimation and risk assessment: A department of transportation case study. 95 $5^{\text {th }}$ Annual Meeting of the Transportation Research Board (TRB), 2016.

[5] Construction Industry Institute (CII). "A guide to construction rework reduction". published by CII Knowledge Base, 2011.

[6] M. Shahparvari, D. Fong. "The review of rework causes and costs in housing construction supply chain"'. In The 26th Annual Conference of the International Group for Lean Construction (IGLC 2018), 2018. https://doi.org/10.24928/2018/0514

[7] R. McKim, T. Hegazy, M. Attalla. "Project performance control in reconstruction projects". Journal of Construction Engineering and Management," 126(2), 137-141, 2000. https://doi.org/10.1061/(ASCE)0733-9364(2000)126:2(137)

[8] Habibi M, Kermanshachi S. "Phase-based analysis of key cost and schedule performance causes and preventive strategies". Engineering, Construction and Architectural Management 25(8), 2018. https://doi.org/10.1108/ecam-10-2017-0219

[9] Habibi M, Kermanshachi S, Safapour E. "Engineering, procurement and construction cost and schedule performance leading indicators: state-of-the-art review". ASCE Construction Research Congress (CRC), 2018. https://doi.org/10.1061/9780784481271.037

[10] E.C. Eze, J.E. Idiake. "Impact of rework on building project and organisation performance: A view of construction professionals in Nigeria". International Journal of Sustainable Construction Engineering and Technology, 9(1), 29-43, 2018. https://doi.org/10.30880/ijscet.2018.09.01.003

[11] Kermanshachi S, Thakur R, Govan P B. "Discovering the impact of late change orders and rework on labor productivity: a water treatment case study analysis using system dynamics modeling”. ASCE Construction Research Congress (CRC), 2018. https://doi.org/10.1061/9780784481295.069

[12] Kermanshachi S, Safapour E. "Investigation and Analysis of Human, Organizational, and Project Based Rework Indicators in Construction Projects". ASCE International Conference On Computing in Civil Engineering, 2019. https://doi.org/10.1061/9780784482438.064

[13] B.G. Hwang, S.R. Thomas, C.T. Haas, C.H. Caldas. "Measuring the impact of rework on construction cost performance." Journal of Construction Engineering and Management, 135(3), 187-198, 2009. https://doi.org/10.1061/(asce)0733-9364(2009)135:3(187) 
[14] Safapour E, Kermanshachi S, Nipa T J. "Analysis of Cost Performance Indicators in Reconstruction Projects: A Comparative Study of Low Vs. High Level Damages". Creative Construction Conference (CCC), 2020

[15] Pamidimukkala A, Kermanshachi S, Kartick S. "Impact of Natural Disasters on Construction Projects: Strategies to Prevent Cost and Schedule Overruns in Reconstruction projects". Creative Construction Conference (CCC), 2020.

[16] A.A. Bilau, E. Witt, I. Lill. "Analysis of measures for managing issues in post-disaster housing reconstruction". Buildings, 7(2), 29, 2017. https://doi.org/10.3390/buildings7020029

[17] M. Attalla, T. Hegazy. "Predicting cost deviation in reconstruction projects: Artificial neural networks versus regression". Journal of Construction Engineering and Management, 129(4), 405-411, 2003. https://doi.org/10.1061/(ASCE)0733-9364(2003)129:4(405)

[18] Y. Chang, S. Wilkinson, D. Brunsdon. "An integrated approach: managing resources for post-disaster reconstruction" Disasters, 35(4), 739-65, 2011. https://doi.org/10.1111/j.1467-7717.2011.01240.x

[19] Safapour E, Kermanshachi S, Nipa T J. "Schedule Performance Analysis of Infrastructure Reconstruction Projects Due to Extreme Events". Creative Construction Conference (CCC), 2020.

[20] Rouhanizadeh, B.; Kermanshachi, S. "A Systematic Approach to Analysis and Prioritization of the Socioeconomic Policies and Legal barriers to Rapid Post Disaster Reconstruction". 7th CSCE International Construction Specialty Conference (ICSC), 2019

[21] D.M. Frangopol, P. Bocchini. "Resilience as optimization criterion for the rehabilitation of bridges belonging to a transportation network subject to earthquake". In Structures Congress 2011, pp. 2044-2055, 2011. https://doi.org/10.1061/41171(401)178

[22] Safapour E, Kermanshachi S. "Identifying early indicators of manageable rework causes and selecting mitigating best practices for construction". Journal of Management in Engineering 35(2),2018. https://doi.org/10.1061/(ASCE)ME.1943-5479.0000669

[23] Safapour E, Kermanshachi S, Taneja P. "Investigation and analysis of the rework leading indicators in construction projects: state-ofthe-art review". 7th CSCE International Construction Specialty Conference (ICSC), 2019. https://doi.org/10.1061/9780784482438.064

[24] M.S. Eid, I.H. El-adaway, "Integrating the social vulnerability of host communities and the objective functions of associated stakeholders during disaster recovery processes using agent-based modeling". Journal of Computing in Civil Engineering, 31(5): 04017030, 2017. https://doi.org/10.1061/(ASCE)CP.1943-5487.0000680

[25] Rouhanizadeh, B.; Kermanshachi, S. "Gender-based evaluation of physical, social, and economic challenges in natural disasters management". ASCE Construction Research Congress (CRC), 2019

[26] Rouhanizadeh, B.; Kermanshachi, S.; Dhamangaonkar, V. "Identification and categorization of policy and legal barriers to long-term timely post-disaster reconstruction". Journal of Legal Affairs and Dispute Resolution in Engineering and Construction, Volume 11 issue 3, 2019. https://doi.org/10.1061/(asce)la.1943-4170.0000307

[27] H.B. Ku, Y.N. Ma. "Rural-Urban Alliance as a new model for post-disaster social work intervention in community reconstruction: The case in Sichuan, China". International Social Work, 58(5):743-758, 2015. https://doi.org/10.1177/0020872815583073

[28] G.R. Webb, K.J. Tierney, J.M. Dahlhamer. "Predicting long-term business recovery from disaster: a comparison of the Loma Prieta earthquake and Hurricane Andrew, Glob. Environ. Change Part B: Environ". Hazards, 4, 45-58, 2002. https://doi.org/10.3763/ehaz.2002.0405

[29] G. Hegar. "Fiscal Notes: A storm to remember: Hurricane Harvey dn the Texas economy" Texas Comptroller of Public Accounts. Retrieved from <https://comptroller.texas.gov/economy/fiscal-notes/2018/special-edition/history.php>, Retrieved at May 31, 2020.

[30] E. Hayat, R.D.G. Amaratunga. "Road reconstruction in post-disaster recovery; the challenges and obstacles." 2011.

[31] R.D. Knabb, J.R. Rhome, D.P. Brown, "Tropical cyclone report, Hurricane Katrina, 23-30 August 2005," National Hurricane Center, Miami, 2006.

[32] R.D. Knabb, J.R. Rhome, D.P. Brown, “Tropical cyclone report, Hurricane Rita, 18-26 September 2005.” National Hurricane Center, Miami, 2006.

[33] Rouhanizadeh, B.; Kermanshachi, S.; Dhamangaonkar, V. "Reconstruction of critical and interdependent infrastructures due to catastrophic natural disasters: lessons learned". ASCE Construction Research Congress, 2019.

[34] Kermanshachi, S.; Bergstrand, K.; Rouhanizadeh, B. "Identifying, weighting and causality modeling of social and economic barriers to rapid infrastructure recovery from natural disasters: A study of hurricanes Harvey, Irma and Maria". Technical report, 2019.

[35] J. Mallela, S. Sadasivam. "Work zone road user costs - Concepts and applications". Federal Highway Administration, U.S. Dept. of Transportation, Washington, DC, 2011.

[36] A. Rose, D. Wei, A. Wein. "Economic impacts of the shakeout scenario," Earthquake Spectra, 27(2), 539-557, 2011. https://doi.org/10.1193/1.3587204

[37] Kermanshachi S, Zheng Y, Anderson S D, Cliff S, Molenaar K R. "Cost Estimating Tool for Early Estimates for Rural and Small Urban Transit Facilities". 95 ${ }^{\text {th }}$ Annual Meeting of Transportation Research Board (TRB), 2016.

[38] Kermanshachi S, Safapour E, Anderson S, Molenaar K R, Cliff S. "Development of the Cost Baseline for Achieving Excellence in Rural Transit Facilities". Transportation Research Board 98 ${ }^{\text {th }}$ Annual Conference, 2018.

[39] N. Zamichow, V. Ellis. "Santa Monica freeway to reopen on Tuesday recovery: The contractor will get a \$14.5-million bonus for finishing earthquake repairs 74 days early." Los Angeles Times, 1994

[40] Safapour, E.; Kermanshachi, S. "Identification and categorization of factors affecting duration of post-disaster reconstruction of interdependent transportation systems". ASCE Construction Research Congress (CRC), 2019.

[41] Pamidimukkala A, Kermanshachi S, Safapour E. Challenges in Post-Disaster Housing Reconstruction: Analysis of Urban Vs. Rural Communities". Creative Construction Conference (CCC), 2020

[42] Nipa T, J., Kermanshachi, S., Ramaji I, J. Comparative analysis of strengths and limitations of infrastructure resilience measurement methods. $7^{\text {th }}$ CSCE International Construction Speciality Conference (ICSC), 2019

[43] Nipa T, J., Kermanshachi, S. Identification of the Resilience Dimensions and Determination of their Relationships in Critical Transportation Infrastructures. ASCE Construction Research Congress (CRC), 2019

[44] L. Wang, M. Kunc, S.J. Bai. "Realizing value from project implementation under uncertainty: An exploratory study using system dynamics". International Journal of Project Management, 35(3), pp.341-352, 2017. https://doi.org/10.1016/j.ijproman.2017.01.009

[45] Safapour E, Kermanshachi S, Habibi M, Shane J. "Resource-based exploratory analysis of project complexity impact on phase-based cost performance behavior". ASCE Construction Research Congress (CRC), 2017. https://doi.org/10.1061/9780784481271.043

[46] Rouhanizadeh, B., \& Kermanshachi, S. "Investigating the Relationships of Socioeconomic Factors Delaying Post-Disaster Reconstruction". In Proceedings of ASCE International Conference on Computing in Civil Engineering, pp. 17-19. 2019. https://doi.org/10.1061/9780784482445.005

[47] Rouhanizadeh, B.; Kermanshachi, S. "Comparative analysis of public's and decision-maker's perspectives on socioeconomic barriers causing delay in post-disaster recovery processes". ASCE Construction Research Congress (CRC), 2019. 
[48] Kermanshachi, S., \& Rouhanizadeh, B. "Feasibility analysis of post disaster reconstruction alternatives using automated BIM-based construction cost estimation tool". In Proceeding of CSCE 6th International Disaster Mitigation Specialty Conference, Montreal: Canadian Society of Civil Engineering, pp. 13-16. 2018.

[49] H.R. Aljailawi, H. Shariatmadar. "The reasons for rework occurrence in construction projects and prioritizing them by using AHP Method," In 2nd. International Conference on Civil Engineering, Architecture and Urban Design, 2017.

[50] D. Amaratunga, R. Haigh, R. Thanurjan, L.I.P. Seneviratne. "The role of knowledge management in post-disaster housing reconstruction." Disaster Prevention and Management: An International Journal 18(1), 2009. https://doi.org/10.1108/09653560910938556

[51] Moloney. "Haitians still homeless "suffering in despair 4 years after quake - Amnesty." Thomson Reuters Foundation, 4-6, 2014.

[52] Hidayat, C. Egbu. "A literature review of the role of project management in post-disaster reconstruction". Proceedings of $26^{\text {th }}$ Annual ARCOM Conference, Association of Researchers in Construction Management, Leeds, 2010.

[53] J. Kennedy, J. Ashmore, E. Babister, I. Kelman,."The meaning of 'build back better': evidence from post-tsunami Aceh and Sri Lanka". Journal of Contingencies and Crisis Management, 16(1), 24-36, 2008. https://doi.org/10.1111/j.1468-5973.2008.00529.x

[54] S.E. Chang, N. Nojima. "Measuring post-disaster transportation system performance: the 1995 Kobe earthquake in comparative perspective". Transportation Research Part A: Policy and Practice, 2001, 35(6), 475-494, 2001. https://doi.org/10.1016/S09658564(00)00003-3

[55] L. A. Ika, A. Diallo, A., D. Thuillier. "Critical success factors for World Bank projects: An empirical investigation". International Journal of Project Management, 30(1), 105-116, 2012. https://doi.org/10.1016/j.ijproman.2011.03.005

[56] R. Matsumaru, K. Nagami, K. Takeya. "Reconstruction of the Aceh Region following the 2004 Indian Ocean tsunami disaster: A transportation perspective". IATSS Research, 36(1), pp.11-19, 2012. https://doi.org/10.1016/j.iatssr.2012.07.001

[57] M.A. Choudhary, K. Mehmood. "Causes of success and failure of post disaster reconstruction projects-A case study of post 2005 earthquake in Northern Pakistan". Planet@Risk, 1(1), 2013.

[58] D. Brunsdon, J. Hare, M. Stannard. "The impact of the Canterbury earthquake sequence on the engineering profession in New Zealand". Paper presented at the Australian Earthquake Engineering Society 2012 Conference, December 7-9, Gold Coast. https://doi.org/10.5459/bnzsee.46.1.56-67

[59] F. Marquis, J.J. Kim, K.J. Elwood, S.E. Chang. "Understanding post-earthquake decisions on multi-storey concrete buildings in Christchurch, New Zealand". Bulletin of Earthquake Engineering, 15(2), 731-758, 2017. https://doi.org/10.1007/s10518-015-9772-8

[60] Almufti, M. Willford. "REDi ${ }^{\mathrm{TM}}$ rating system: Resilience-based earthquake design initiative for the next generation of buildings," 2013. https://doi.org/10.13140/RG.2.2.20267.75043

[61] Rouhanizadeh B, Kermanshachi S. "Challenges and Strategies Incorporated with Transportation Construction Inspection". ASCE Construction Research Congress (CRC), 2019. 